sity of Bristol and was accorded the title of emeritus professor.

At the start of the Second World War, Travers offered his services to the Royal Ordnance Factories, and, as a consultant, threw himself whole-heartedly into the diverse problems which had to be solved. He made many contributions, particularly in connexion with the application of silicon iron in sulphuric acid manufacture, and in the development of rocket cordite. In his dealings with technological problems he had a remarkable facility for putting his finger on the source of trouble. It was amazing to see a man, who was for most of the War more than seventy years of age, travel many miles, usually at night, to face the problems in the widely scattered ordnance factories. In this period he was a wonderful example to the younger scientists and technologists in his untiring enthusiasm for work.

Soon after the end of the War, Travers moved to Stroud and began what was for him one of his greatest and most congenial tasks, the production of a full biography of Sir William Ramsay. This work, which Travers had began in 1937, was taken up again in 1948, and the book was written between Travers's eighty-first and eighty-third birthdays; it is one of the great biographies of our time and it will surely remain as a monument to Sir William Ramsay and a fitting memorial to Travers.

Prof. Travers is survived by his wife, formerly Miss Dorothy Gray, a pianist of outstanding ability, whom he married in 1909 , by their daughter and by their son, who is now professor of educational psychology at the University of Utah.

I am indebted to Mr. S. W. G. Morgan, Dr. W. G. Hiscock and Mr. J. Lumsden, of the Imperial Smelting Corporation, for providing information about Travers's industrial career.

D. H. EVERETT

\section{Prof. R. H. Dastur, O.B.E.}

INDIA has lost a distinguished plant physiologist and agronomist by the death of Prof. R. H. Dastur, which occurred at Bombay on October 1, 1961, at the age of sixty-five years.

Rustom Hormusji Dastur was born on March 7, 1896. After gradusting as bachelor of science in 1918 at the Gujarat College, Ahmedabad, he was appointed a demonstrator in botany at the same College and obtained the M.Sc. degree in botany, by research, in 1921. His association at the Gujarat College with the noted botanist Prof. W. T. Saxton gave young Dastur a good grounding in systematic botany and ecology. Dastur's interests, however, turned very early in his career towards plant physiology, despite the fact that he had little regular training in plant physiological research, except perhaps for $a_{0}$ year (1924-25) he spent at the University of Reading, England, with Prof. W. Stiles. There he experimentally tested his earlier ideas on the relation of water content to photosynthesis (Ann. Bot., 38, 779; 1924) and made a new departure by measuring photosynthesis in a leaf attached to the plant (Ann. Bot., 39, $769 ; 1925$ ).

Dastur was appointed assistant lecturer in botany at the Royal Institute of Science, Bombav, in 1921, and continued there as professor and head of the Department of Rotany during 1929-1935. During this period of about half a decade he established a very active school of plant physiology, and his investigations, in collaboration with his pupils, related to the influence on photosynthesis of factors such as water and chlorophyll content, and quality and polarization of light, physiology and anatomy of tendrils, respiration, and physiology of the rice plant. The results of these investigations were published in the Annals of Botany, the Journal of the Indian Botanical Society and the Indian Journal of Agricultural Science.

In the year 1935 Dastur's interest shifted from the academic to the applied side of plant physiology, and work on the cotton erop claimed his entire interest for the next 26 years and constituted the magnum opus of his scientific output.

In 1919 the crop of the Panjab-American cotton, hitherto the main standby of the cultivator in the canal colonies of the Panjab, suffered a serious setback when it was attacked by a disease called 'tirak'. By 1935, another seven failures of the crop, partial or complete, occurred. Various theories were advanced to explain this condition but none satisfactorily accounted for and solved the mystery of the occasional failures of the crop. Prof. Dastur was then invited by the Indian Central Cotton Committee to undertake investigation into this problem, and it was indeed a far-sighted and bold step on the part of the Committee and Mr. H. R. (later Sir Herbert) Stewart, the then director of agriculture, Panjab, to pin their faith on one who until he undertook the investigation had no previous contact with or knowledge of the cotton plant. This investigation, carried out from 1935 until 1943 and described in several scientific pupers and eventually in a monograph, was reviewed in Nature (158, 524; 1946). Sir Herbert Stewart summed it up in the words: "The story which it unfolds is a striking example of how investigations into the realm of pure science can be turned to practical account in everyday agricultural practice".

Dastur retired from service in 1951 on attaining the age of fifty-five years. The Indian Central Cotton Committee, however, retained his services in an honorary capacity until the time of his death for directing and supervising plant physiological and agronomic research schemes on cotton.

During 1944-61, Prof. Dastur was engaged in investigations on: (1) causes of bad opening of bolls in Sind; (2) causes of the low yield of sea-island and Egyptian cottons in the verious cotton-growing tracts: (3) causes of red-leaf disease and several other related aspects, and obtained a number of important and useful results. These results were compiled in two other monographs which were published by the Indian Central Cotton Committee in 1959 and 1960. Prof. Dastur was in the process of constructing a theory for the application of fertilizers on the basis of a balance between nitrogen, phosphorus and potas. sium contents of the plant, and it is indeed unfortunate that death claimed him before he could complete this interesting and useful concept.

Dastur had a reserved, but gentle and kindly disposition and hunned publicity; he virtually lived for his work and had little interest in social activities and scientific conferences which would take him away from it. For his work on cotton in the Panjab he was made O.B.E. in 1946. He was a Foundation Fellow of the National Institute of Sciences of India and was elected president of the Botany Section of the Indian Science Congress in 1933 and of the Indian Society for Plant Physiology in 1959.

He leaves behind a widow, a daughter, a son and a large circle of pupils and colleagues who will cherish his mernory for a long time to come.

R. D. Asana 